\title{
POTENSI EKSTRAK DAUN PINUS (Pinus merkusii Jungh. et de Vriese) SEBAGAI BIOHERBISIDA PENGHAMBAT PERKECAMBAHAN Echinochloa colonum L. DAN Amaranthus viridis.
}

\author{
Potencies of Pine Leaf Extract (Pinus merkusii Jungh. et de Vriese) as Germination Bioherbicides Inhibitor \\ for Echinochloa colonum L. and Amaranthus viridis \\ Yusuf Andi Senjaya dan Wahyu Surakusumah
}

\begin{abstract}
The allelopathic substances are organic agents which are produced and released by a plant that cause alteration on the neighboring plants. The characteristics of allelochemicals usually inhibit germination of other species and sometime will reduce growth of the other species which associate with the producer of allelochemicals. The mechanism of allelochemicals can be used to suppress a germination of Echinochloa colonum L. and Amaranthus viridis $\mathrm{L}$. These plants are weeds species of rice. The aims of this research were to study the allelochemicals effect from the leaf of pines (Pinus merkusii Jungh. et de Vriese) on germination of Echinochloa colonum L. and Amaranthus viridis L.. The experimental design used Completely Randomized Design with five replicates for each concentration (0, 250, 500, 750, 1000 ppm). The result which was analyzed with One-Way Analyze of Varians (ANOVA) indicated that giving a pine leaf extracts had an inhibitor effect on germination of $E$. colonum $L$. and $A$. viridis $L$.
\end{abstract}

Key words: Pinus merkusii Jungh. et de Vriese, allelopathy, weeds, Echinochloa colonum L., Amaranthus viridis $\mathrm{L}$.

\section{PENDAHULUAN}

Pinus merupakan tanaman yang dapat digunakan untuk reboisasi, karena pinus memiliki beberapa fungsi, di antaranya sebagai tanaman pelindung tanah secara ekologis dan sebagai penghasil kayu. Selain itu, pinus juga memiliki daya kompetitif yang besar terhadap tumbuhan lain di sekitarnya sehingga mampu bersaing (Marisa, 1990). Pinus merkusii memiliki saluran resin yang dapat menghasilkan suatu metabolit sekunder bersifat alelopati (Taiz and Zeiger, 1991). Alelokimia pada resin tersebut termasuk pada kelompok senyawa terpenoid, yaitu monoterpen apinene dan $\beta$-pinene (Harborne, 1987; Taiz and Zeiger, 1991). Senyawa ini diketahui bersifat toksik baik terhadap serangga maupun tumbuhan. Selain itu, senyawa tersebut merupakan bahan utama pada pembuatan terpentin. Monoterpen (C-10) merupakan minyak tumbuh-tumbuhan yang terpenting yang juga bersifat racun (Sastroutomo, 1990).

Beberapa kajian ekologis pada daerah pertumbuhan pohon pinus menunjukkan tidak ada pertumbuhan tanaman herba, yang diduga karena serasah daun pinus yang terdapat pada tanah mengeluarkan zat alelopati yang menghambat pertumbuhan herba. Hal tersebut diperkuat dengan penelitian terhadap kemampuan daun pinus yang belum terdegradasi yang dapat menurunkan pertumbuhan panjang radikula kecambah sawi (Marisa, 1990). Hal tersebut menunjukkan bahwa kandungan senyawa pada daun Pinus merkusii mempunyai potensi sebagai bahan bioherbisida untuk mengontrol pertumbuhan gulma yang dapat menganggu pertumbuhan produksi tanaman pangan antara lain tanaman padi. Salah satu gulma yang mengganggu pertumbuhan tanaman padi adalah E. colonum dan $A$. viridis.

Pengendalian gulma pada dasarnya adalah suatu usaha untuk mengubah keseimbangan ekologis yang bertujuan menekan pertumbuhan gulma, tetapi tidak berpengaruh negatif terhadap tanaman budidaya. Dengan demikian diharapkan dengan adanya pengolahan tanah, waktu tanam, pemupukan, jarak tanam dan varietas yang tepat, dapat menekan pertumbuhan gulma sehingga persaingan antara tanaman dengan gulma tidak dapat terjadi. Biasanya tanaman sangat peka 
terhadap faktor lingkungan pada umur sepertiga sampai setengah umur tanaman. Maka pada saat itulah waktu yang tepat untuk dilakukan pengendalian gulma (Sukman dan Yakup, 2002).

Berbagai upaya telah dilakukan untuk memberantas atau mengendalikan pertumbuhan gulma ini, salah satunya adalah dengan menggunakan herbisida. Penggunaan herbisida sintetis yang berlebihan dapat mengakibatkan pencemaran lingkungan, karena sifatnya yang sulit terurai dalam tanah sehingga meninggalkan residu atau terjadi pengendapan bahan toksikan pada medium tanah (bioakumulasi) dan biomagnifikasi (pembesaran kadar bahan toksikan melalui rantai makanan). Hal tersebut dapat membahayakan organisme lain terutama manusia sebagai konsumen terakhir (biomagnifikasi) pada rantai makanan dari tanaman padi ini.

Adanya fenomena tersebut menjadi pemicu timbulnya banyak penelitian yang berusaha mencari solusi, yaitu suatu bahan alami yang dapat digunakan sebagai bioherbisida yang sifatnya aman karena mudah terdegradasi dalam tanah sehingga tidak meninggalkan residu. Salah satu hasil penelitian yang dapat dijadikan alternatif dalam penggunaan herbisida adalah pemanfaatan mekanisme alelopati dari suatu tumbuhan.

Untuk mengkaji potensi tersebut maka dilakukan penelitian yang bertujuan untuk menguji efektivitas daya hambat ekstrak daun pinus terhadap perkecambahan gulma E. colonum dan $A$. viridis.

\section{BAHAN DAN METODE}

Daun pinus segar sebanyak 100 gram dihancurkan dengan blender. Hancuran daun dimasukkan ke dalam labu Erlenmeyer berukuran $250 \mathrm{ml}$, lalu ditambahkan aseton $70 \%$ sebanyak $200 \mathrm{ml}$ dan kemudian dimaserasi (menggunakan shaker $125 \mathrm{rpm}$ ) selama 24 jam. Hancuran yang telah dimaserasi ini disaring dengan kertas saring sehingga didapatkan filtratnya. Filtrat disimpan dalam labu takar $1000 \mathrm{ml}$ untuk kemudian diekstrak kasar. Apabila belum diekstrak kasar pada saat yang sama, filtrat disimpan dalam inkubator $10^{\circ} \mathrm{C}$, agar tidak mengalami perubahan kimiawi. Sementara itu, residu hancuran daun pinus ditambah lagi dengan aseton $70 \%$ sebanyak 200 $\mathrm{ml}$ dan kembali dimaserasi selama 24 jam, untuk kemudian disaring. Pekerjaan ini dilakukan berulang-ulang sehingga filtrat yang tersaring tidak lagi berwarna (bening). Pada saat akhir akan didapatkan filtrat sebanyak 1 liter. Pekerjaan yang sama dilakukan kembali sampai didapatkan filtrat sebanyak 2 liter. Larutan hasil filtrasi ini diekstrak kasar dengan "Vaccuum Rotary Evaporator".

Vaccuum Rotary Evaporator adalah alat yang berfungsi untuk memisahkan suatu larutan dari pelarutnya sehingga dihasilkan ekstrak dengan kandungan kimia tertentu sesuai yang diinginkan. Cairan yang ingin diuapkan biasanya ditempatkan dalam suatu labu yang kemudian dipanaskan dengan bantuan penangas, dan diputar. Uap cairan yang dihasilkan didinginkan oleh suatu pendingin (kondensor) dan ditampung pada suatu tempat (receiver flask). Kecepatan alat ini dalam melakukan evaporasi sangat cepat, terutama bila dibantu oleh vakum. Terjadinya bumping dan pembentukan busa juga dapat dihindari. Kelebihan lainnya dari alat ini adalah diperolehnya kembali pelarut yang diuapkan. Prinsip kerja alat ini didasarkan pada titik didih pelarut dan adanya tekanan yang menyebabkan uap dari pelarut terkumpul di atas, serta adanya kondensor (suhu dingin) yang menyebabkan uap ini mengembun dan akhirnya jatuh ke tabung penerima (receiver flask). Setelah pelarutnya diuapkan, akan dihasilkan ekstrak yang dapat berbentuk padatan (solid) atau cairan (liquid) (Nugroho, et al. 1999). Biasanya ekstrak yang dihasilkan dari ekstraksi awal ini (ekstraksi dari bahan tumbuhan) disebut sebagai ekstrak kasar (crude extract).

Pada penelitian ini Vaccuum Rotary Evaporator diset pada suhu $60^{\circ} \mathrm{C}$ karena titik didih aseton (pelarut) berkisar antara $56,48-94,3^{\circ} \mathrm{C}$, sedangkan kisaran titik didih terpen adalah sekitar 150-180oC pada tekanan atmosfer dan khususnya untuk kisaran titik didih a-pinen adalah sekitar $154,7^{\circ} \mathrm{C}$ (Guenther, 1987). Hasil akhir dari proses ekstraksi ini adalah berupa ekstrak kental yang didapatkan dari 2 liter filtrat lebih kurang 15 gram, dan disimpan dalam inkubator sebelum digunakan untuk perlakuan. Untuk mendapatkan konsentrasi ekstrak yang diinginkan adalah dengan melarutkan ekstrak kental yang dianggap berkonsentrasi 100\% di dalam air sumur.

Uji daya hambat dilakukan dengan menambahkan ekstrak daun pinus dengan konsentrasi $250 \mathrm{ppm}, 500$ ppm, 750 ppm dan 1.000 ppm pada masing-masing media perkecambahan $E$. colonum dan $A$. viridis serta sebagai kontrol digunakan perkecambahan 
tanaman padi. Penentuan daya hambat ditentukan berdasarkan perbandingan jumlah biji yang tidak berkecambah dibandingkan dengan perlakuan kontrol (tanpa ditambahkan ekstrak daun pinus).

\section{HASIL DAN PEMBAHASAN}

Penelitian ini bertujuan untuk mengetahui bagaimana pengaruh ekstrak daun pinus segar terhadap perkecambahan $E$. colonum dan $A$. viridis pada konsentrasi yang berbeda. Sebelum dilakukan uji daya hambat ekstrak daun pinus terhadap proses perkecambahan dilakukan terlebih dahulu optimasi untuk menentukan medium perkecambahan dan waktu perkecambahan. Berdasarkan hasil pra penelitian didapatkan bahwa medium perkecambahan dengan kapas merupakan medium terbaik untuk perkecambahan dibandingkan dengan medium kertas singkong dan kertas pulp. Waktu optimum untuk perkecambahan adalah selama 2 minggu.

Berdasarkan hasil penelitian didapatkan bahwa penambahan ekstrak daun pinus pada medium perkecambahan dapat mengakibatkan terjadinya penurunan perkecambahan $E$. colonum dan A. viridis seperti terlihat pada Tabel 1 dan Gambar 1.

Data pada Tabel 1 menunjukan bahwa penambahan konsentrasi ekstrak daun pinus pada media perkecambahan menyebabkan peningkatan biji yang tidak dapat berkecambah. Pemberian larutan ekstrak daun pinus terhadap biji $A$. viridis dan $E$. colonum pada kelima konsentrasi (termasuk kontrol) yang berbeda, menunjukkan perbedaan yang signifikan terhadap jumlah biji yang berkecambah. Proses yang terjadi pada biji $A$. viridis dan $E$. colonum ini adalah terhambatnya proses perkecambahan karena adanya senyawa alelopati yang terkandung dalam ekstrak daun pinus segar.

Pada konsentrasi tertentu senyawa alelokimia dapat menghambat dan mengurangi hasil pada proses-proses utama tumbuhan. Hambatan tersebut misalnya terjadi pada pembentukan asam nukleat, protein, dan ATP. Jumlah ATP yang berkurang dapat menekan hampir seluruh proses metabolisme sel, sehingga sintesis zat-zat lain yang dibutuhkan oleh tumbuhan pun akan berkurang (Rice, 1984;

Table 1. The effects of pine leaf extract added against germination of E. colonum dan A. Viridis.

\begin{tabular}{lccc}
\hline \multirow{2}{*}{$\begin{array}{l}\text { Konsentrasi ekstrak daun } \\
\text { pinus (ppm) }\end{array}$} & \multicolumn{3}{c}{ Perkecambahan (\%) } \\
\cline { 2 - 4 } & Amaranthus viridis & Echinochloa colonum & Oryza sativa \\
\hline Kontrol & 0 & 0 & 0 \\
250 & $55,9 \pm 2,1$ & $50,0 \pm 2,3$ & $98,2 \pm 0,6$ \\
500 & $54,4 \pm 1,3$ & $41,7 \pm 3,5$ & $97,4 \pm 0,4$ \\
750 & $52,9 \pm 0,9$ & $33,3 \pm 2,6$ & $96,1 \pm 0,3$ \\
1000 & $38,2 \pm 1,1$ & $16,7 \pm 1,7$ & $90,1 \pm 1,1$ \\
\hline
\end{tabular}

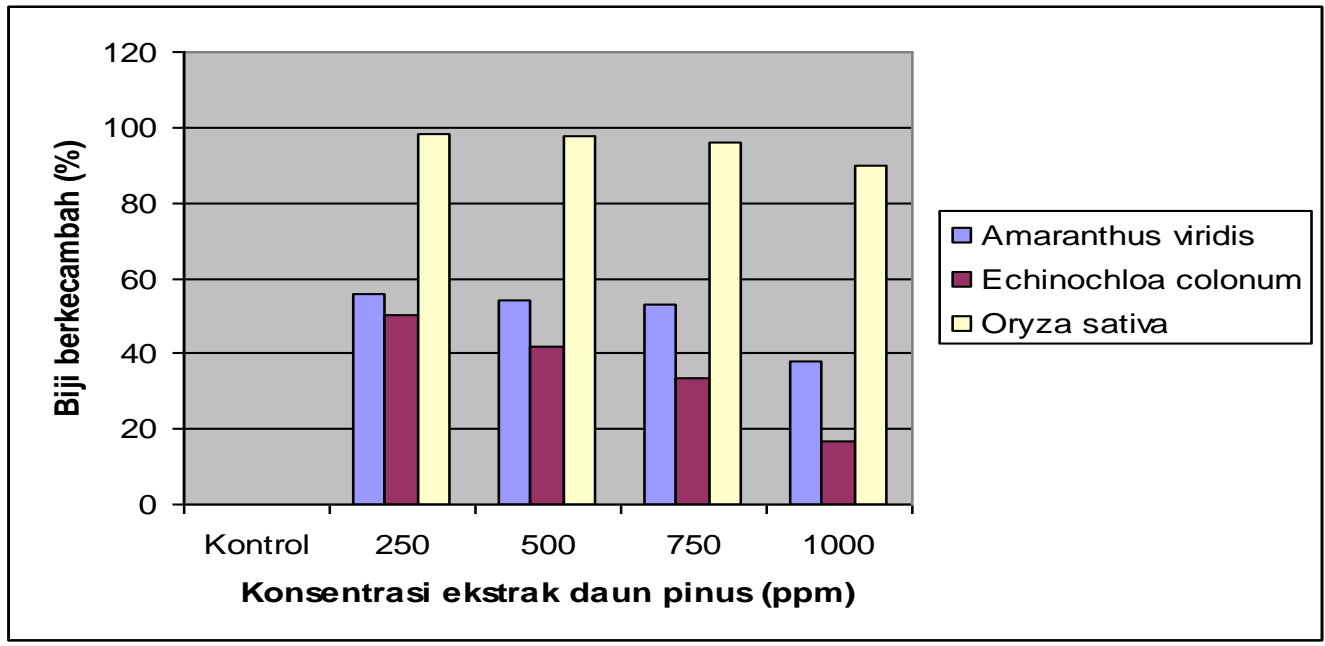

Figure 1. The inhibitor effects of pine leaf extract. 
Salisbury and Ross, 1992). Masuknya senyawa allelopati bersama air ke dalam biji akan menghambat induksi hormon pertumbuhan seperti asam giberelin (GA) dan asam indolasetat (IAA) (Yuliani, 2000). Dengan dihambatnya sintesis giberelin maka tidak akan terjadi pemacuan enzim a-amilase, akibatnya proses hidrolisis pati menjadi glukosa di dalam endosperma atau kotiledon berkurang. Pada gilirannya jumlah glukosa yang dapat dikirim ke titik-titik tumbuh lebih sedikit (Rice, 1984). Berkurangnya komponen makromolekul mengakibatkan terhambatnya sintesis protein yang juga akan berakibat pada terhambatnya sintesis protoplasma (Yuliani, 2000). Oleh karena itu, proses pembelahan dan pemanjangan sel terhambat, yang berakibat pada terhambatnya proses perkecambahan dan pertumbuhan. Bahkan, walaupun terjadi proses perkecambahan banyak kecambah yang tidak normal atau cacat (Einhellig, 1986 dalam Yuliani, 2000).

Senyawa alelopati pada Pinus merkusii antara lain pinene dan tanin. Senyawa pinene dapat berpengaruh pada sistem metabolisme tumbuhan yang dapat mengakibatkan gangguan fungsi sel. Mekanisme senyawa pinene berlangsung pada organel yang disebut sitokrom yaitu sitokrom P 450 dan bekerjasama dengan sitokrom b5 yang terletak berdekatan dengan sitokrom P 450. Sitokrom ini terletak pada perbatasan permukaan luminal dinding sel dengan permukaan sitoplasma. Senyawa pinene yang masuk ke dalam sel akan segera dioksidasi dan akan mempengaruhi metabolisme sel (Marisa, 1990).

Selain senyawa pinene, senyawa toksik yang terdapat pada pinus adalah tanin yang termasuk kelompok senyawa fenolik. Penelitian sebelumnya membuktikan bahwa tanin dapat menghambat pertumbuhan hipokotil, menghilangkan kontrol respirasi pada mitokondria serta mengganggu transpor ion $\mathrm{Ca}^{2+}$ dan $\mathrm{PO}_{4}{ }^{3}$. Selain itu, senyawa tanin juga dapat menonaktifkan enzim amilase, proteinase, lipase, urease, dan dapat menghambat aktivitas hormon giberelin (Marisa, 1990).

Pemberian larutan ekstrak daun pinus terhadap biji Oryza sativa pada kelima konsentrasi (termasuk kontrol) yang berbeda, menunjukkan tidak ada perbedaan yang signifikan terhadap jumlah biji yang berkecambah. Penelitian ini dilakukan di dalam ruangan laboratorium dengan suhu $25,53^{\circ} \mathrm{C}$, kelembaban $60,95 \%$, dan intensitas cahaya 56,58 Lux. Faktor lingkungan yang diukur tersebut adalah faktor yang kemungkinan berpengaruh terhadap proses perkecambahan.
Berdasarkan data yang telah dianalisis dengan uji Anova One-Way dan dilanjutkan dengan uji Tukey, diperoleh hasil bahwa pada konsentrasi 1.000 ppm ekstrak daun pinus samasama berpengaruh menghambat perkecambahan gulma $A$. viridis, $E$. colonum dan berpengaruh menghambat pertumbuhan Oryza sativa sebesar $10 \%$ sebagai tanaman budidaya pada lahan persawahan. Hal tersebut menunjukkan bahwa ekstrak daun pinus ini berpotensi sebagai bioherbisida.

\section{KESIMPULAN}

Mengacu pada hasil penelitian dapat diambil kesimpulan bahwa:

1. Ekstrak daun pinus berpengaruh menghambat perkecambahan $A$. viridis dan $E$. colonum.

2. Konsentrasi larutan ekstrak daun pinus yang lebih berpengaruh menghambat perkecambahan biji $A$. viridis dan $E$. colonum adalah pada $1.000 \mathrm{ppm}$.

3. Pemanfaatan larutan ekstrak daun pinus sebagai bahan bioherbisida pada konsentrasi $1.000 \mathrm{ppm}$ dapat mempengaruhi perkecambahan tanaman padi.

\section{DAFTAR PUSTAKA}

Harborne, J.B. 1987. Metode Fitokimia. Penerbit Institut Teknologi Bandung. Bandung.

Marisa, H. 1990. Pengaruh Ekstrak Daun Pinus (Pinus merkusii Jungh. et de Vriese) terhadap Perkecambahan dan Pertumbuhan Vegetatif Tanaman Kedelai (Glycine max (L.) Merr.). Tesis Pasca Sarjana Biologi. Institut Teknologi Bandung. Bandung.

Nugroho, B.W., Dadang, dan D. Prijono. 1999. Pengembangan dan Pemanfaatan Insektisida Alami. Pusat Kajian Pengendalian Hama Terpadu, Institut Pertanian Bogor. Bogor.

Rice, E. L. 1984. Allelopathy. Academic Press, Inc. London.

Salisbury, F.B. and C.W. Ross. 1992. Plant Physiology. Wardsworth Publishing Company. California.

Sastroutomo, S.S. 1990. Ekologi Gulma. Gramedia Pustaka Utama. Jakarta. 
Sukman, Y. dan Yakup. 2002. Gulma dan Teknik Pengendaliannya. Raja Grafindo Persada. Jakarta.

Taiz, L. and E. Zeiger. 1991. Plant Physiology. The Benjamin/Cummings Publishing Company, Inc. California.

Diterima : 12 November 2007

Yusuf Andi Senjaya dan Wahyu Surakusumah

Lab. Ekologi

Jurusan Biologi, FMIPA Universitas Pendidikan Indonesia JI Setiabudhi No 229 Bandung Jawa Barat.

Telp/ Fax: 022-2001937. Indonesia
Yuliani. 2000. Pengaruh Alelopati Kamboja (Plumeria acuminata W. T. Ait.) terhadap Perkecambahan Biji dan Pertumbuhan Kecambah Celosia argentea L.". CHIMERA, Jurnal Biologi dan Pengajarannya. Universitas Negeri Malang. Malang. 